Accepted refereed manuscript of:

Graziano M, Fox C, Alexander K, Pita C, Heymans JJ, Crumlish M, Hughes AD, Ghanawi J \& Cannella L (2018) Environmental and socio-political shocks to the seafood sector: What does this mean for resilience? Lessons from two UK case studies, 1945-2016, Marine Policy, 87, pp. 301-313.

DOI: 10.1016/j.marpol.2017.10.014

(C) 2017, Elsevier. Licensed under the Creative Commons AttributionNonCommercial-NoDerivatives 4.0 International http://creativecommons.org/licenses/by-nc-nd/4.0/ 


\section{Environmental and socio-political shocks to the seafood sector: what does this mean for resilience? Lessons from two UK case studies, 1945-2016}

Marcello Graziano, ${ }^{1,7 *}$ Clive J. Fox, ${ }^{2}$ Karen Alexander, ${ }^{1,3}$ Cristina Pita, ${ }^{4,8}$ J.J. Heymans, ${ }^{2}$ Margaret Crumlish, ${ }^{5}$ Adam Hughes, ${ }^{2}$ Joly Ghanawi, ${ }^{5}$ Lorenzo Cannella. ${ }^{6}$

${ }^{1}$ Laurence Mee Centre for Society and the Sea, Scottish Association for Marine Science, Scottish Marine Institute, Oban PA37 1QA, UK.

${ }^{2}$ Scottish Association for Marine Science, Scottish Marine Institute, Oban PA37 1QA, UK.

${ }^{3}$ Centre for Marine Socioecology, University of Tasmania, Hobart TAS 7001, Australia.

${ }^{4}$ Department of Environment and Planning \& Centre for Environmental and Marine Studies (CESAM), University of Aveiro, Campus Universitário de Santiago, 3810-193, Aveiro, Portugal. Portugal

${ }^{5}$ Institute of Aquaculture, School of Natural Sciences, University of Stirling, Stirling FK9 4LA, UK.

${ }^{6}$ Scienze del Mare, Dipartimento di Scienze della Terra, dell'Ambiente e della Vita, University of Genova. C.so Europa 26, 16132, Genoa, Italy.

${ }^{7}$ Department of Geography, Central Michigan University, Dow Science Complex 279, Mount Pleasant, MI 48859, USA.

${ }^{8}$ Institute of Biological and Environmental Sciences, University of Aberdeen, Aberdeen AB24 2TZ, UK

* Contact author: Marcello Graziano, Department of Geography, Central Michigan University, Mt. Pleasant (MI), USA. P: +1 989-774-1627. E: grazi1m@cmich.edu.

Keywords: consolidation; employment; farmed Atlantic salmon; NEA mackerel; resilience; shocks.

\section{Acknowledgements}

The authors would like to thank Prof Kenny Black (Scottish Association for Marine Science) for sharing his extensive knowledge about salmon aquaculture in Scotland; Dr Liam Campling (Queen Mary University of London) for providing invaluable feedback before the workshop; Andrew Parker (IMANI Consulting) for his insights about regional development and the role of seafood production. Mr. Ian Gatt, Scottish Pelagic Fishermen's Association, and Mr. Ian McFadden, Scottish Pelagic Processors Association Ltd, for their insights about the mackerel fishing industry, mackerel trade and markets. This work is dedicated to the memory of Professor Laurence Mee.

\section{Funding}

This work was supported by the Marine Alliance for Science and Technology Scotland (MASTS) Fisheries Research Theme, SAMS Learned Society, and the EU-FP7 Marine Energy Research Innovation \& Knowledge Accelerator (MERIKA) project. Cristina Pita was funded by FCT/MEC national funds and FEDER co-funding, within the PT2020 partnership Agreement and Compete 2020, for the financial support to CESAM (Grant N UID/AMB/50017/2013). 


\section{Introduction}

Fisheries products have become globally traded commodities which has led to increasing degrees of export dependency for producing regions (Brookfield et al, 2005; Salz and MacFayden, 2007; Jones et al, 2014). Such dependency generates several social and economic risks which become accentuated at times of challenge to supply or demand (European Commission, 2010; Campling et al., 2012; Jennings et al., 2016). The complexities inherent in the relations of exploitation and commodification (Campling et al. 2012) are also influenced by extra-sectoral factors, such as natural ecological shifts in productivity and politically-influenced free-trade agreements. Jennings et al. (2016) suggested that sectoral-based analyses for fisheries often overlook important elements such as links with environmental changes, human health and fish welfare. Recognising this transdisciplinary complexity, the present work examines how two export-orientated sectors of major significance to the UK, farmed Atlantic salmon (an aquaculture product) and North-east Atlantic mackerel (a capture fishery) have responded to ecological, environmental and socio-political shocks, and how they have maintained their microeconomic (i.e. sectoral) and macroeconomic (regional) viability.

The seafood industry is mediated by complex relationships within and across national boundaries (Jennings et al., 2016). Producing regions, such as Scotland, may be part of a larger nationstate (in this case the United Kingdom) whilst engaging with wider trading partnerships, such as the European Economic Area (Österblom et al., 2015). Although individual companies compete for market share, they may also collaborate for mutual benefit (Havice and Campling, 2017), e.g. on product labelling, trading of fishing quotas or production standards (Sumaila et al., 2016). Furthermore, because of the limited scope for further expansion of most capture fisheries, aquaculture has been identified as a "focus area" with significant scope for further expansion, giving the seafood industry a dual nature, composed of fisheries and aquaculture.

In this multidisciplinary examination of these two seafood sectors, this work applies both a sectoral and a regional (UK) perspective. As the UK is currently a member of the EU, both these sectors have to abide by both national and EU-level policies, the latter regulated through the Common Fisheries 
farming sectors were chosen for this study based on their importance to UK seafood production: NEA mackerel is consistently the most landed species by Scottish vessels, accounting on average for $28 \%$ of landings by weight and $18 \%$ of landings by value (Seafish, 2015); Atlantic salmon is the most important reared fish in the UK, accounting for nearly $99 \%$ of the total UK aquaculture production by weight in 2012 (MGSA, 2014), and the most sold, imported and exported seafood product by value (Seafish, 2015b). The specific objectives of this study were to investigate: 1) how these two sectors have responded to environmental, economic and geopolitical shocks which accompanied and influenced their development; 2) to identify how structural differences or similarities between these two sectors have influenced their ability to respond to these shocks; 3) to examine whether the degree of consolidation within these two sectors has conferred economic resilience and how such resilience may influence their future development. Consolidation is here defined as the aggregation at production level of multiple firms through Concentration and Centralization, foreign direct investment (FDI), and Association as defined by Havice and Campling (2017). Resilience is here defined and understood within the conceptualization proposed by Brand and Jax (2007) of 'ecological-economic' resilience, and following the definition of Perrings (2006). More generally, the term resilience can be traced to the post-classical, 'engineering-analogue' meaning (Holling, 1996) introduced by Holling (1973) (Chandler, 2014). Therefore, in this work the term 'resilience' describes the ability of a sector to adapt to exogenous shocks. However, as it will be argued in the conclusions, this work also identifies a trend of rising exposure to shocks linked to the expansion of these two sectors.

\section{Methods: Applying Transdisciplinary}

A three-day expert workshop was held in August 2015 to collectively analyse data and literature on both sectors and to identify "red flags" linked with changes in production and trade flows. For the purposes of this study, "red flags" were defined as elements which could be susceptible to future abrupt temporary and, or permanent changes (i.e. risks). This approach has been used to identify key risk factors across a wide-range of disciplines e.g. in medical diagnosis (Henschke et al., 2013; Martino

94 et al., 2013), domestic violence (Austin and Drozd, 2012), terrorism financing (Gordon, 2011) and 
methodology for "red flag analysis" and therefore, in this instance, it was used as part of an expert-led, qualitative approach.

The experts were comprised of seven researchers and two $\mathrm{PhD}$ students, in fisheries and aquaculture and included ecologists, biologists, economists and social scientists from a range of research organisations. The workshop was split into two components: data collection and analysis.

\section{$2.1 \quad$ Data collection}

Contextual information and production/landings data for each industry was collated and analysed. The workshop participants with a life-sciences background were split into two smaller groups (one focused on salmon, the other on mackerel) based on relevant expertise, and data was collected and written up separately by each group, then fed back to the larger group for analysis. Social scientists worked within both teams, and acted as transdisciplinary links to identify social and economic differences/similarities between the two sectors, based on the published literature reviewed. Information on the history of the development of both industries were obtained through searches of the Aquatic Sciences and Fisheries Abstracts (ASFA, 2016) database spanning 1971-2015. Governmental grey literature was examined when relevant to sectoral and national policies associated with or influencing these industries.

Production data for farmed Atlantic salmon came from the on-line databases FishStatJ (Version 2.12.4; 1950-2013) and Eurostat (www.ec.europa.eu) as well as reports from the Scottish Salmon Producers Organisation (SSPO). Information on market trends was retrieved from FAO Globefish (www.globefish.org). Data on the landings of NEA mackerel were taken from FishStatJ (Version 2.12.4, 1950-2013) and the UK Sea Fisheries Annual Statistics (MMO, 2015). Trade-flow information came from the Fisheries Commodities Production and Trade dataset (1976-2011). Further contextual information for mackerel was obtained from official stock assessment reports generated by ICES (www.ices.dk) and the UK Sea Fisheries Annual Statistics (MMO, 2015). Information was compiled regarding: international and national actors (i.e. firms operating at the production level and their associations), domestic policies and objectives for industry development, industry characteristics (e.g. composition and size) and markets (both international and domestic). During the collection of 
124 contextual information, ecological, social and political shocks which had affected the industries were

125 identified, as well as how the sector had responded.

\subsection{Data analysis}

During the data analysis component of the workshop, the participants were brought back together into one larger facilitated group to discuss findings, to collectively identify 'red flags' (those elements of the industry which may be affected by shocks to the sector) and to assess, for each 'red flag', whether the regional sector had limited, some or strong resilience to the identified shocks (Table 1). The expert judgements (backed up by information and data collated in the previous component) derived from this part of the workshop were then entered into a traffic light plot. of this expert-panel approach is, thus, not as immediate as formal quantitative methodologies, and is influenced by the regional focus of the sectors. Qualitative approaches are also difficult to synthetize into single summary metrics but offer an opportunity to better understand the cause-effect relationships of complex, transdisciplinary structures as fisheries production systems.

\section{Farmed Atlantic salmon - case study of large-scale aquaculture}

Driven by increasing global demand (Braekkan and Thyholdt, 2014) the world-wide output of

144 farmed salmon has grown steadily since the early 1980s, reaching > 2.2 million tonnes in 2013 (a 400fold increase), with Atlantic salmon accounting for around 91\% of the production (Figure 1).

\section{- Figure 1 About Here -}

Aquaculture now provides around $67 \%$ of the global production of all salmon species

148 (FishStatJ, 2014) with Atlantic salmon farms concentrated in Norway, Chile and the UK (within the

149 UK salmon farming is predominantly based in Scotland). Outside of these countries, production of 150 Atlantic salmon is increasing, but remains relatively low. Although the industry was initially small- 
scale, the industry is dominated by a few trans-national corporations (Marine Harvest, 2015, Asche et

152 al., 2013). Appendix D shows in detail the concentration and internationalization of the markets across

153 the largest producing countries. In some instances, for example the UK, value-addition takes place in

154 the country of origin, but the product is often exported fresh or frozen for processing, especially to 155 countries with lower labour costs, such as Poland (Ciszewska-Mlinaričet al 2014). Some of these export 156 flows are also influenced by trade-tariffs: e.g., fresh or frozen Norwegian salmon attracts a lower tariff 157 (0\%) than the smoked product (15\%) when imported into the EU (European Commission, 2016).

158 Salmon farming is thus highly internationalized with actors operating across national boundaries either 159 at the production, trade or both levels (Figure 2). (FishstatJ, 2014). During its expansion in the UK, the industry received substantial investments in research and development which have led to improvements in animal health and welfare, as well as product quality (Alexander et al, 2014). Along with effective marketing, this has secured 'Scottish salmon' as a recognisable premium-brand within the global market. More recently, adoption of certification programmes, such as the Royal Society for the Prevention of Cruelty to Animals (RSPCA, 2016) and Welfare Standards and Global Good Agricultural Practice (GAP, 2016), have helped further standardise production across the industry. These standards encompass animal health and welfare but also incorporate technological advances designed to mitigate negative environmental and social impacts (RSPCA, 2015).

173 Scottish industry set itself a growth target of reaching 210,000 tonnes output by 2020 , a $30 \%$ increase 174 from 2012, a target also incorporated into Scotland's National Marine Plan (Scottish Government, 2015; 175 MGSA, 2014). The overall objective is to generate new, sustainable jobs, especially in rural areas 176 (Alexander et al., 2014), and to improve exports, with a new target set at $£ 7.1$ bn for 2017 (up from 
Recently salmon has become the largest single seafood product consumed in the UK,

180 contributing $15 \%$ of total seafood consumption by volume and $26 \%$ by value (Seafish, 2015). Producers

181 have seen a continued increase in domestic demand for both imported and domestically grown salmon,

182 despite an overall long-term decrease in national household expenditure on seafood (EUMOFA, 2015).

183 However, the export market is an essential component, accounting for $73 \%$ of the domestically farmed

184 product (DEFRA, 2014; Globefish, 2015). Salmon is exported to approximately 55 countries (Scottish

185 Government, 2015), mainly in the EU (France, Ireland, and Poland) but also to the USA. Sales to new

186 markets, such as China have also been increasing reaching $6.3 \%$ of production in 2013 (DEFRA, 2014).

\section{$187 \quad 3.2 \quad$ Responses to shocks affecting salmon aquaculture}

For farming systems, disease represents a major risk which can significantly and sometimes

189 abruptly affect production. Whilst considerable progress has been made in the use of vaccines and

190 probiotics to prevent outbreaks, some infections have had significant impacts on the farmed salmon

191 sector. Major outbreaks of viral Infectious Salmon Anaemia (ISA) in particular have caused high

192 mortalities in affected farms, starting in Norway in 1984 (See Appendix A). The 1998 ISA outbreak in

193 Scotland led to major changes in the way farmed salmon is produced in the UK. According to Hastings

194 et al. (1999), the outbreak cost more than $£ 20$ million to eradicate but led to the development of

195 improved prevention and control procedures, ultimately strengthening the resilience, of the production

196 sector to disease, i.e. the ability to adapt to maintain its level of service delivery. The ISA outbreak that

197 affected Chile in 2007 is considered to have had an even greater impact (EFSA 2012) and the crisis was

198 exacerbated by irregularities in monitoring and assessment within the control framework (Barton and

199 Floysand 2010). Ultimately the outbreak led to a significant restructuring of the Chilean sector and a

200 direct loss of 1,866 jobs (Marine Harvest 2008). Globally, the Chilean epidemic led to a shortage of

201 farmed salmon causing price increases and a temporary restructuring of the market (Asche, 2009;

202 EFSA, 2012). 
204 the salmon farming industry. In 2010 the Norwegian Nobel Committee awarded the Peace Prize to Liu

205 Xiaobo, a Chinese human rights activist and this led to non-tariff border measures being 206 disproportionately applied by China against Norwegian salmon - a tool popularised as the 'Dalai Lama 207 effect' (Sverdrup-Thygeson, 2015). Measures applied by the Chinese authorities included more frequent sanitation and veterinary testing of Norwegian salmon and a more restrictive licensing regime

209 (political shock). These measures were predicted to have long-term consequences for Norwegian trade 210 because, along with oil, seafood is a major Norwegian export (Chen and Garcia, 2015). The negative 211 impact on Sino-Norwegian trade was however less severe than originally predicted. Norway actually 212 managed to increase its exports to China through the identification of new channels including airports 213 and ports which did not previously import salmon, and by re-routing through third-parties e.g. Vietnam. 214 However, this has also led to market distortion with increasing volumes of salmon being smuggled and 215 quality degradation, which in turn has led to a deterioration of Chinese consumer confidence in the 216 product (Chen and Garcia, 2015). Other salmon exporting countries seem to have benefited from the 217 non-tariff border measures since the quantity and value of Scottish salmon exports to China actually 218 increased from a very low level in 2009 to nearly 10,000 tonnes in 2013 (with a value of $\sim 50 \mathrm{M}$ ). In 219 August 2014, Russia introduced a one-year trade ban on imports of agricultural products, raw materials and food from the EU, USA, Canada, Australia and Norway as a response to sanctions sparked by the crisis in the Ukraine (political shock). Russia was previously the main destination for seafood exports from Norway and seventh in the list of major export partners of seafood for the EU (Motova and Natale, 2015). Farmed salmon was the top seafood commodity affected by this trade-ban (representing $48.3 \%$ of the total seafood imports banned in 2013 with a value of $€ 566 \mathrm{M}$ ) (Motova and Natale, 2015). For a while, Norway was able to circumvent the import ban by exporting via Belarus, but this loop-hole was closed by the Russian government in 2016. The Russian embargo also affected the price of farmed salmon causing it to drop by almost 9\%, although this fall was short-lived (Holter, 2014; Globefish, 2014). Due to its diverse trade network, Norway was able to divert the majority of its surplus product to the EU, particularly to established markets such as the UK and Portugal (Holland, 2015). For Scottish

230 producers, Russia had not been a strong export market and thus the Russian trade-ban had a negligible 
impact on the UK industry, apart from the short-lived price fluctuation (Globefish, 2015). The response

232 of salmon producers to these geo-political shocks has been to redirect their export flows to existing and 233 emerging markets with untapped demand captured through lower prices (Globefish, 2015), a strategy

234 in line with the structure of the sector (Figure 2), and visible in the changes in trade patterns (see Figure 2354 in section 5 for further discussion).

\subsection{Present and future perspectives for farmed Atlantic salmon}

Increasing demand for salmon, including in emerging markets with large populations, such as

Brazil, China and Russia (Braekkan and Thyholdt, 2014), and the limited and/or declining capacities of capture fisheries (FAO, 2014), suggest that the expansion of demand for Atlantic salmon is likely to continue. Indeed, the UK (mainly Scotland) plans to substantially expand its salmon production by 2020

241 (Scottish Government, 2015b). Similar increases are planned in established production centres (e.g. Norway, Research Council of Norway, 2015) as well as new countries entering the sector (e.g. Ireland, Australia, see Department of Agriculture, Food and the Marine, 2015; FRDC, 2015). are expected to continue, while new conflicts may arise due to space-competition with other capitalintensive blue-growth activities (Johnson et al., 2012). Larger, highly capitalized companies with production across multiple countries (e.g. Marine Harvest) have greater agility to hedge local risks across multiple producing regions. However, and partly because of their export-oriented, large-scale structure, these companies might expose the producing regions to further shocks, because of an inherent mismatch between "[...] the scale of management and the scale(s) of the ecological processes being managed" (Cumming et al., 2006, p.1), (Poppy et al.2014; Hospes and Kentin, 2014). Trade-wise, the recent Brexit vote and the increasing competition from within the EU (increasing production in Ireland), and other non-member countries, such as Russia, are introducing new sources of uncertainty, at a time of overall demand growth. Finally, the future of salmon aquaculture will rely heavily on the stability of fish oil supplies, mainly from the volatile Peruvian anchovies fisheries (Fox, 2014), which have recently experienced rising price trends (Ytrestøyl et al. 2015), thus making feed pricesa potential source of future shocks. Despite considerable success with substitution and research into alternative sources, fish- 
meal and fish-oil remain essential components in the pelleted feeds for salmon at present (Tacon et al.,

259 2011; Ytrestøyl et al. 2015).

\section{Large-scale capture fisheries: North-East Atlantic mackerel}

Mackerel is a medium-sized, pelagic shoaling fish which is widely distributed in the North-east

Atlantic. Within the EU, NEA mackerel provide the second highest capture landings by volume (FishStatJ, 2014). In the UK, most of the pelagic vessels are based in Scotland and the majority of

264 Scottish landings are exported for human consumption (MMO, 2015). Historically, mackerel landings increased in the mid-1960s, followed by a decline but then rebuilt and have since fluctuated between 400,000 and 800,000 tonnes per year (Figure 3). The national actors began to change dramatically in 2007 (Figure 3) as significant amounts of mackerel began appearing in Icelandic and Faroese waters prompting these countries to begin commercial harvesting (Jensen et al, 2015).

At producer level, the Scottish freezer-trawler pelagic fleet relies heavily on co-operation through association (ICES, 2014b; Seafish, 2013). The fishery is mainly prosecuted by large freezertrawlers which account for $99 \%$ of the landings (by volume): they operate mid-water trawls or purseseines in seasonal fisheries for mackerel, herring (Clupea harengus) and blue whiting (Micromesistius poutassou) (pers. comm. Ian Gatt, Scottish Pelagic Fishermen's Association). Most of the vessels are based in ports in the north-east of Scotland (Fraserburgh, Peterhead and Lerwick), are family-owned, and are members of the Scottish Pelagic Fishermen's Association (SPFA). ${ }^{1}$ Compared with the salmon

277 farming sector the Scottish NEA mackerel sector therefore possesses stronger local ties and has a lower influence of foreign ownership.

The internationally shared nature of the mackerel stock makes the fishery reliant on effective public-sector-led multi-national agreements for issues such as the setting of catch quotas. Compared with farmed salmon, this shifts the locus of decision-making from individual firms, to national and international levels. Scottish interests are presently represented at EU level through the UK fisheries

\footnotetext{
${ }^{1}$ See Appendix B for a detailed list of vessels and ownership.
} 
minister, whilst UK interests are represented by the EU in the North East Atlantic Fisheries Commission

284 (NEAFC), an international body whose members includes all the major producing countries: Norway,

285 Iceland, Denmark (on behalf of the Faroe Islands and Greenland), and Russia. Based on stock assessments conducted by ICES, NEAFC allocates a quota to its members within their catching areas, and, in the case of Russia, outside of their exclusive economic zone (Hannesson 2014). The EU quota is then shared between the relevant countries, who in turn pass it on to their Producer Organisations to allocate among vessels.

\subsection{The NEA mackerel fisheries as a traded commodity and its significance to the UK}

In 2014, mackerel represented the most economically important single species for UK fishing vessels with landings at 128,200 tonnes, worth $£ 105.5$ million representing around $17 \%$ of the total national landings by value (MMO, 2015). Of this, $97 \%$ by weight was landed into Scottish ports and a further 29,300 tonnes was landed to UK ports by foreign vessels. An almost equal amount $(159,800$ tonnes) was landed into foreign ports by UK (mainly Scottish) vessels, making the Scottish pelagic fleet one of the most profitable within the UK (MMO, 2015). Catches of NEA mackerel have also increased since the mid-2000s, as a result of increases in stock abundance (ICES, 2015).

The UK mackerel industry has traditionally been export oriented, although the export destinations have changed over time (Figure 4). In the 1970s, factory ships from the Soviet Union would visit Western Scotland, and other parts of the UK, to take on-board fish caught by local vessels (the socalled Klondike fishery, Beare and Reid, 2002). This remained a common practice until the end of the 1980s when the break-up of the Soviet Union led to the demise of the Klondike fisheries (Connell, 1983). During the following two decades, NEA mackerel continued to play an important role in UK seafood exports, mainly to Western and Eastern Europe but also to some non-European countries (Seafish, 2015). As of 2016, the Netherlands was the most important market for UK mackerel catches, followed by Nigeria (MMO, 2015). Significant amounts were still being exported to Russia, although this trade-flow was caught up in the embargoes imposed by that country on EU Agricultural and Food

310 products. Despite health-related promotions by the UK government to encourage consumption of oily 311 fish (Levy, 2015), NEA mackerel has continued to suffer from low levels of domestic consumption, 
312 both by sales volume and value (Seafish, 2015), making it increasingly important for UK producers to

313 identify new and maintain existing export markets.

As previously mentioned, the UK pelagic fleet is located mainly in ports in eastern Scotland, which are outside of the most socio-economically fragile areas of the country. Even in Shetland, the mackerel industry is located in a region with above-average income and relatively low rates of unemployment (EDUS, 2011). Within these areas the pelagic sector provides significant high-value employment, mainly through crew-share systems (Marine Scotland, 2013), whilst the associated transport and processing operations provide further employment, both in situ and in the rest of Scotland (Seafish, 2006). The largest pelagic ports by landing volumes are also in areas with potentially more alternative employment, which is an important factor considering the seasonality of this fishery and the sector's vulnerability to external shocks (e.g. export embargoes).

\subsection{Responses to shocks affecting the NEA mackerel fisheries}

In the early 2000s, an ecological shock occurred as the spatial distribution of the mackerel stocks began to change (Hannesson, 2014; ICES, 2014; Hughes et al., 2015; Jensen et al, 2015). This has led to an international dispute (political shock) which has, in turn, led to over-harvesting in relation to the recommended total allowable catches advised by ICES. The series of disputes between the EU, Norway, Faroes and Iceland has been dubbed the Mackerel Wars and remains only partially resolved (Hannesson, 2014; Jensen et al, 2015). The underlying cause of the biological change is unclear and has been linked with climate (Astthorsson et al. 2012, Hughes et al. 2015), although other analyses favour

334 a density-dependent range expansion driven by an overall increase in stock abundance (van der Kooij et al. 2015). As mackerel started appearing in their waters, and despite a new regional agreement in 2008 between the EU, Norway and the Faroe Islands, unilateral action was taken in 2009 by Iceland and the Faroe Islands to increase their catches. A lack of agreement on the Management Plan led to unilateral quotas being set, which taken together, are higher than the total recommended catch indicated by the scientific advice (ICES 2014). In 2014, the EU, Norway, and the Faroes approached ICES with a draft request on a revised long-term management plan which ICES evaluated as being consistent with 
the precautionary approach (ICES 2014). Prior to these events the NEA mackerel fishery was generally

342 regarded as being well-managed, despite prosecutions of some skippers/owners for quota-busting (STV

343 News, 2012 and the Shetland Times, 2012), and the major fisheries had been awarded Marine

344 Stewardship Certification (MSC) in 2009. Because of the international situation, MSC decided to suspend certification for the pelagic trawl, purse-seine and hand-line NEA mackerel fisheries. As of 2015, the main European fisheries formed a new collaborative organisation, the Mackerel Industry

347 Northern Sustainability Alliance (MINSA) with the purpose of going through re-assessment. This was

348 successful and MSC certification was reinstated as of May 2016, despite Iceland still not being party to 349 the 2014-2018 Coastal States Agreement Management Plan, although it should be noted that a 350 Condition to the MSC Certification was raised in this regard (Acoura Marine Ltd., 2016). difference with salmon farming. In capture fisheries, although the individual companies are smaller, they operate within international fisheries frameworks negotiated by state level actors (Figure 5). To some extent this encourages collective action to solve mutual problems (e.g. through the creation of MINSA) but it also means that the companies are largely powerless if the international relationships, on which the fisheries agreements are based, become dysfunctional.

Although the setting of unilateral mackerel quotas by Iceland and Faroes has had some effect on Scottish landings, the impacts of other recent "political" shocks have been more significant. The

362 Scottish mackerel industry has suffered due to the loss of markets caused by the 2014 Russian seafood embargo and the collapse of the Ukrainian economy (pers. comm. Ian Gatt, Scottish Pelagic Fishermen's Association) (Figure 6). Although Russia was a relatively un-important market for Scottish farmed salmon (described in section 3.1) it was the third largest importer of mackerel from the UK accounting for 10,508 tonnes in 2014 (MMO, 2015). Following the ban on EU seafood imports, the UK government examined options for increasing exports to new and traditional markets such as China, United States, Nigeria, and Turkey. Globefish (2014) reported that this had been partly successful, 
although a drop in prices was observed, an occurrence normally associated with over-supply

370 (IceFishNews, 2015). The active role of the UK government and the focus on extra-EU markets suggests

371 that there is little un-tapped domestic demand for mackerel making the UK NEA mackerel fisheries

372 heavily dependent on foreign markets.

373 The disruption of trade-flows has primarily affected UK and EU producers, whilst the new entrants, Iceland and the Faroes, have benefited (Motova and Natale, 2015). As a consequence, UK producers have directed some of their product to another historic market, Nigeria, but the sudden inflow of seafood products to that country has caused the Nigerian government to introduce restrictions aimed at limiting the outflow of currency. Although these restrictions were partially lifted in 2015, the recent collapse of oil prices has also impacted Nigerian purchasing power for imported products.

\subsection{Present and future perspectives for NEA mackerel}

Sustainable yields of NEA mackerel are predicted to be around 700,000 tonnes per year (ICES, 2015). However, MSY yields predicted by ICES are lower than the present combined harvest so fishing mortality, needs to be reduced. The most recent stock assessment from ICES shows that although the spawning stock biomass is well above $\mathrm{B}_{\text {msy-trigger }}$, it has begun to decline (ICES, 2017). In December 2015 the EU, Norway and Faroe Islands reached an agreement for a revised mackerel management plan which enacted a 15\% cut in quotas in 2016 and also allows a 15\% share for other coastal states (DEFRA, 2015b). However, Iceland remains disengaged from the latest negotiations, thus increasing the source of uncertainty for the UK sector.

As of 2016/2017, the social impacts of the recent shocks on the UK mackerel industry appear to have been relatively limited because the industry and policymakers have been able to adapt quickly.

393 The loss of the Russian market represented approximately $20 \%$ of the primary pelagic processors' turn394 over but the well organised UK industry was able to respond rapidly, leveraging Scottish and UK government support to find new outlets (Ian Gatt, pers. comm.). The UK government has also supported moves to allow 'banking' of quota which cannot be exported due to the Russian embargo (Defra, 2015). 
397 More recently, the EU and Norway have initiated talks for allowing duty-free seafood imports from

398 Norway, which might cause further friction between EU-members (SPPO website, Aug 2015). If the

399 alternate export markets, such as Nigeria, become further restricted due to concerns over currency

400 outflow, falling oil income, and the former market (Russia) continues to be supplied by the new entrants

401 (Iceland and Faroes), there may be longer term problems for marketing mackerel caught by the UK

402 fleet.

403

It is also possible that the spatial distribution of the stock could revert to its former pattern, in

which case harvesting by the new entrants might cease (Astthorsson et al. 2012). However, the longterm sustainability of the mackerel fisheries will only be guaranteed if binding international agreements on quota-sharing can be reached between all the nations fishing on this stock. In addition, the "Mackerel Wars", have clearly demonstrated that the fisheries management plans were not robust to such changes. This is somewhat surprising, and worrying, given that such distribution changes might have been anticipated as mackerel have historically appeared in Icelandic waters during warmer periods (Astthorsson et al. 2012). Furthermore, future changes in the distribution of many fish species have been predicted in response to anticipated climate change (Rutterford et al., 2015; Montero-Serra, 2014;

412 Cheung et al., 2012).

\section{Results: identifying similarities and differences in response between the salmon and mackerel sectors.}

The results of the "red flag" analyses (Table 2) identify several similarities and differences in

417 how the two sectors have been able to respond to the shocks described above, and how these responses

418 are related to the different structural organisations of the two sectors. Although both sectors have 419 become highly, although differently, concentrated they experienced two different forms of aggregation: concentration (salmon), and association (NEA mackerel). In contrast to Norway, where the state was a major share-holder in salmon feed and farming operations (until 2014), and in research facilities

422 (Rainbird and Ramirez, 2012; Huemer, 2012), expansion in the UK took place with more limited direct state-intervention. The UK Atlantic salmon farming industry has become consolidated mainly through commercial buy-outs resulting in a few companies with a large element of foreign direct investment 
425 (FDI), although some UK-owned operators still exist. Salmon farming also operates largely under 426 national environmental standards which differ between countries. In contrast, the UK NEA mackerel 427 fishery became highly concentrated mainly as a result of government-assisted programs which were 428 designed to reduce fishing capacity. The UK NEA mackerel sector is now a highly controlled (through association), domestic industry comprised of vessel-owner companies, fishing an internationally shared stock which is regulated by agreements between states. relationships where workers are waged employees. Although sector-specific data are not available for

434 NEA mackerel, the pelagic fleet traditionally uses a share system, where each crew member receives a share of the catch, after running costs are paid (McCall Howard, 2012). The system makes fishermen self-employed, risk-sharing associates with the vessel owner to maximize the catch (McCall Howard, 2012).

An additional difference in the labour relations between these two sectors is the spatial extent and flexibility of their operations. Fish farms are fixed in their location and, because of the logistical problems in moving large volumes of live fish from farm to processor, their downstream value chain operations (e.g. gutting and packing plants) are often located near production units (Alexander et al., 2014). Farm workers often reside locally in the communities where the production is based. Landing of

443 NEA mackerel is less spatially constrained so that Scottish vessels landed about $50 \%$ of their catch into 444 non-UK ports (MMO, 2015). For mackerel landed into UK ports, the majority of value-added 445 processing operations are also located in more populated areas of Scotland (Garret, 2010), thus reducing 446 the economic impact of the sector's supply chain to the immediate areas around the producing ports. 447 The UK fishing sector as a whole also tends to employ workers from a wider range of localities, 448 including internationally (MMO, 2015). As a consequence of these employment patterns, the farmed 449 salmon sector will generate more localized negative employment impacts during times of crisis (Pita et 450 al., 2010), as exemplified in the cases of the Chilean collapse of 2008/2009 (Asche et al, 2009) and 
recent restructuring by Marine Harvest in Scotland (Fish Update, 2016) and Gregs Seafood's in

452 Shetland (Fish Update, 2016b).

On the supply-side, both sectors rely on healthy natural ecosystems to maintain their

454 production. However, shocks to certain capture fish stocks do affect the production of farmed Atlantic salmon because the sector still relies on fish-oil (and to a lesser extent fish-meal) which is produced mainly by Latin American, German, and Danish industrial fisheries (Ytrestøyl et al. 2015; Fox, 2015;

GlobeFish, 2013). The outlook for fish oil, as well as for soybean protein (another important food source for Atlantic salmon), remains one of increasing prices due to constrained supply (GlobeFish, 2013), for example fish-oil prices have increased by $221 \%$ in real terms between 2003 and 2013 (Globefish, 2013).

Research into alternate sources, such as genetically-modified terrestrial crops, is being actively supported by policy makers and the industry but acceptability of GMO products in food-production remains particularly controversial in countries such as Scotland (Tocher, 2015; Scottish Government, 2015). However, if sufficient progress into alternatives is not made, a sudden increase in input prices could cause problems for further expansions in salmon farming. Companies farming in Norway and the UK are likely to try and offset the increases in feedstock prices by reducing labour costs through increased automation and efficiency savings, particularly given the comparatively high labour costs in these countries, with direct impacts on employment levels in local communities. The NEA mackerel fishery, on the other hand, has to cope with the natural stock volatility, including fluctuating recruitment and changes in fish growth rates, although in recent years there has been a run of strong year-classes (ICES, 2017; Jansen and Burns, 2015). mackerel sectors, especially in terms of the domestic market. For farmed salmon there still appears to

473 be untapped demand in the UK, EU and emerging markets and the Scottish product in particular enjoys 474 a high market status, although prices have declined as overall supply has increased. Producers of farmed 475 Atlantic salmon therefore seem able to find outlets for increased production which has helped reduce 476 the negative impacts from crises, such as recent trade-embargoes (Globefish, 2015). Overall the global increase in production has driven prices down, but increased the marketability of the product (Globefish, 
2015). However, this places one of the main drivers for increases in UK production outside of its control, so that the Scottish industry will be somewhat susceptible to supply/price fluctuations driven by changes in the volumes produced in the other main salmon farming countries, such as Norway and Chile.

The difference between UK domestic demand for salmon and mackerel is a result of Atlantic salmon becoming increasingly seen as a staple within the UK diet (Seafish, 2015c). For NEA mackerel, the internal UK market appears to be largely saturated despite recent health-motivated marketing campaigns encouraging more domestic consumption of oily fish (Levy, 2013). The NEA mackerel sector has therefore not been able to stimulate domestic demand to the same extent as for farmed salmon and thus relies mainly on export markets.

Although the analysis above highlighted significant differences in how the two sectors have responded to historical shocks, this work also identified a number of similarities. Firstly, both sectors supply seafood mainly for human consumption rather than industrial use. Although the EU still has some uncapped demand for salmon, both sectors are now looking towards emerging markets for outlets for their medium-term expansion. Scottish salmon farmers have been focussing on the potential of

493 China, Russia, and Middle Eastern countries (Alexander et al., 2014) whilst for mackerel, the 494 connections with West Africa have already been described. Both sectors are therefore becoming increasingly reliant on exporting to potentially geopolitically unstable and economically volatile regions. These countries have also shown a willingness to use trade-sanctions as a tool linked with political disputes largely un-connected with the export product itself (Sverdrup-Thygeson, 2015). From the supply-side, both sectors display a high degree of inter-firm control, as defined by Havice and

499 Campling (2017) and employ capital-intensive practices, which increases barriers for local new 500 entrants. At the same time, the market concentration/association, following the consolidation at the 501 production stage, have made it possible for both sectors to exhibit resilience to the recent shocks.

503 production (Brookfield, 2005) but there is a substantial difference between the geographical 504 distributions of the two workforces. As mentioned previously most workers on the salmon farms live 
locally whereas Scottish East Coast fishers are traditionally quite mobile (Coull, 1991). Many operate

506 from west-coast bases, often on a near-permanent basis, with weekend commuting by road to their

507 homes (Coull, 2005; Pita, 2010). The producing areas of NEA mackerel have already experienced a

508 partial diversification to other sectors (within and outside the seafood sector, see e.g. Graziano et al.,

509 2017), and are geographically closer to major economic centres. One last point concerns the result of

510 the Jun 2016 Brexit referendum. When the UK leaves the European Union, there will undoubtedly be

511 substantial implications for fisheries management and seafood trade. However, because of the minimum

512 two-year timeline for re-negotiations following the triggering of Article 50, and the multitude of options

513 available to the engaged parties, this could not be considered further in the present paper.

\section{$514 \quad$ 6. Discussion and Conclusions}

This work investigated how the two major high-volume seafood sectors in the UK have responded to several historical environmental, economic and geopolitical shocks which have impacted

517 their development. Although aquaculture is often thought of as being quite different to capture fisheries,

518 this analysis found that both Scottish salmon farming and the Scottish NEA mackerel capture fisheries

519 share some characteristics which have allowed them to be resilient to the major environmental and socio-political shocks which have affected them in recent years. Despite the different ways in which the two sectors are organised, the findings suggest that the main reason for their resilience is that they have both developed into highly inter-firm controlled, and internationally-oriented industries. Most of the demand shocks which have arisen from trade embargoes have been absorbed through effective

524 marketing), by utilising spare demand across multiple countries (i.e. examples of Association and 525 Chain-Governance, Havice and Campling, 2017), hedging environmental risks across multiple producing regions (FDIs and Concentration, through increased intensity of capital), or by working with government agencies to negotiate new opportunities as either blocks of industries (Association) or large regional actors (Centralization). In these cases, the results were made possible because these seafood sectors are characterized by relatively few, well-organized, and financially stable players with the

530 resources and leverage to respond to the issues, i.e. from consolidation in these sectors. The impacts of 531 these shocks on the total output from these sectors has therefore been relatively small, suggesting that 
these two sectors have been effective at maintaining seafood production and their contribution to overall

533 food security in the face of these challenges. However, there were differences in the manner in which

534 government intervened. Scottish government support for salmon farming has been mainly through indirect measures to improve efficiency, such as the Scottish Marine Plan and changes to the way farm site applications are evaluated. The planned increases in production originated from the industry and are expected to be achieved mainly through private investments, whether foreign or domestic. In contrast, the Scottish NEA mackerel fishery has been supported through more direct intervention by the UK and Scottish governments, at the request of the producers' associations, through help with finding new export outlets and in negotiating quota-banking arrangements at EU level.

The main lesson to have emerged from the analysis is that consolidation, both occurring in the past (mackerel) or at present (salmon) at production level appears to be a powerful route for strengthening sector resilience, but this should not be taken to mean that bigger is always better.

544 Although consolidation appears to have conferred resilience for these two highly-industrialised, export-

545 focussed sectors, this work has not examined the counter-factual i.e. whether less-consolidated seafood 546 production sectors would be less resilient (Crona et al., 2016). The relationship between export-oriented 547 production and the more-globalised risks that this exposes the sectors to, suggests that resilience in itself is a complex relational state, one that belongs to the understanding of the complexities faced, rather than to the acquisition of a permanent tranquillity (Brand and Jax, 2007; Chandler, 2014). exploitation of local markets, and further research is needed to understand how less-consolidated businesses have dealt with previous internal and external shocks. successful, but the resilience of the pelagic sector overall seems to benefit from their co-operation via strong Producer Associations. Furthermore, the benefits of consolidation do not automatically confer ecological sustainability. Without effective management, resource over-exploitation can occur in almost any fisheries system (Longhurst, 2010). an industry which cuts across environmental, ecological, economic and political spheres, and it is well 
560 placed within emerging approaches in ecosystem-based management and analysis of seafood sectors

561 (e.g. Jennings et al., 2016; Voss et al., 2016).

562 Based on this experience, five further research questions are formulated, which would benefit 563 from similar multi-disciplinary analysis:

1) Have smaller-scale, export-oriented seafood sectors been affected by similar shocks and if so, how did they react?

2) Does size influence the regional and sectoral economic capacity to cope with shocks? Are less consolidated, more locally-oriented sectors more or less resilient?

3) Are there alternatives to consolidation which will increase the resilience of the seafood production sector?

4) How can such resilience be successfully embedded within coherent (sensu Jordan and Halpin, 2006) seafood production and rural development policies?

5) How can government best support the development of a resilient seafood sector and so promote seafood security?

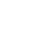

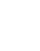

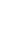


Alexander, K. A., Gatward, I., Parker, A. (2014) An Assessment of the Benefits to Scotland Aquaculture. Marine Scotland. At http://www.gov.scot/Resource/0045/00450799.pdf, last accessed on 011/07/2016.

Asche, F., Hansen, H., Tveteras, R., Tveterås, R. (2009) The Salmon disease crisis in Chile. Marine Resource Economics 24. 405-411.

Asche, F., Dahl E., Gordon D., Trollvik T., Aandahl P. (2011) Demand Growth for Atlantic Salmon: The EU and French Markets. Marine Resource Economics, 26(4): 255-265.

Asche, F., Roll K. H., Sandvold H. N., Sørvig A., Zhang D. (2013) Salmon aquaculture: Larger companies and increased production. Aquaculture Economics \& Management, 17: 322-339.

Aquatic Sciences and Fisheries Abstract- Aquatic Sciences and Fisheries Abstracts (ASFA). FI Institutional Websites. In: FAO Fisheries and Aquaculture Department [online]. Rome. Updated. At http://www.fao.org/fishery/asfa/en, last accessed on 11/07/2016.

Astthorsson, O. S., Valdimarsson, H., Gudmundsdottir, A., Óskarsson, G. J. (2012) Climaterelated variations in the occurrence and distribution of mackerel (Scomber scombrus) in Icelandic waters. ICES Journal of Marine Science, 69: 1289-1297.

Austin, W. G., Drozd, L.M. (2012) Intimate partner violence and child custody evaluation, Part I: Theoretical framework, forensic model, and assessment issues. Journal of Child Custody, 9(4): 250-309.

Beare, D. J., Reid D. G. (2002) Investigating spatio-temporal change in spawning activity by Atlantic mackerel between 1977 and 1998 using generalized additive models. ICES Journal of Marine Science, 59:711-724.

Braekkan,, E. H., Thyholdt, S. B. (2014) The Bumpy Road of Demand Growth - An Application to Atlantic Salmon. Marine Resource Economics, 26(4): 339-350.

Brand, F.S., Jax, K. (2007). Focusing the meaning(s) of Resilience: resilience as a descriptive concept and a boundary object. Ecology and Society, 12(1):23-39.

Brazel, J. F. Carpenter T., Jones K. L., Thayer J. M. (2012) Do Nonprofessional Investors React to Fraud Red Flags? At http://ssrn.com/abstract=1534888, las accessed on 02/02/2016.

Brookfield, K., Gray T., Hatchard, J. (2005) The concept of fisheries-dependent communities: a comparative analysis of four UK case studies: Shetland, Peterhead, North Shields, and Lowestowft. Fishery Research, 72: 55-59.

Campling, L., Havice, E., Howard, P. (2012) The Political Economy and Ecology of Capture Fisheries: Market Dynamics, Resource Access and Relations of Exploitation and Resistance. Journal of Agrarian Change, 12(2-3):177-203. Routledge.

Chandler, D. (2014). Resilience - The governance of complexity. New York (NY), USA:

Chen X., Garcia R. J., (2015) China's Salmon Sanction. Norwegian University of Life Sciences School of Economics and Business Working Papers No. 5 / 2015. At http://www.nmbu.no/sites/default/files/pdfattachments/hh_wp_5_2015.pdf, last accessed on $05 / 09 / 2015$.

Cheung, W. W., Pinnegar, J., Merino, G., Jones, M. C., Barange, M. (2012) Review of climate change impacts on marine fisheries in the UK and Ireland. Aquatic Conservation: Marine and Freshwater Ecosystems 22(3): 368-388. 
635

636

637

638

639

640

641

642

643

644

645

646

647

648

649

650

651

652

653

654

655

656

657

658

659

660

661

662

663

664

665

666

667

668

669

670

671

672

673

674

675

676

677

678

679

680

681

682

683

Ciszewska-Mlinarič, M., Mlinaričąsowska, A., Wąsowski, K. (2014). Socio-Economic Development and Competitiveness: Poland. In: Geo-Regional Competitiveness in Central and Eastern Europe, the Baltic, and Russia (eds A. Zhuplev and K. Liuhto), 1st edn. Hershey (PA, USA), pp. 289317.

Connell, J. (1983) Cold war or not, Soviet ships process Scottish mackerel. Christian Science Monitor. At http://www.csmonitor.com/1983/1025/102551.html, last accessed on 08/07/2016. 40-46.

Coull, J.R. (1991) Mobility in the Scottish fisheries. Scottish Geographical Journal,107 (1):

Coull, J. (2005) The development of fishing communities with special reference to Scotland. In: Managing Britain's marine and coastal environment: towards a sustainable future. (eds Smith, H.D., J.S Potts), Taylor \& Francis Group, Oxon, UK., pp. 139-156.

Crona, B. I., Basurto, X., Squires D., Gelcich, S., Daw, T. M., Khan, A., Havice, E., et al. (2016) Towards a typology of interactions between small-scale fisheries and global seafood trade. Marine Policy, 65: 1-10.

Cumming, G. S., Cumming, D.H.M., Redman, C.L. (2006). Scale mismatches in socialecological systems: causes, consequences, and solutions. Ecology and Society, 11(1): 14.

Department for Environment, Food \& Rural Affairs (DEFRA, 2014) FOI Dossier: UK Exports \& Imports of Salmon (2003-2013). DEFRA Reply - March $25^{\text {th }}$ and February $7^{\text {th }}$ ).

Department of Agriculture, Food and the Marine (DEFRA, 2015) National strategic plan for sustainable aquaculture development - June 2015. At

http://www.agriculture.gov.ie/media/migration/customerservice/publicconsultation/sustainableaquacul turedevelopment/NatStratPlanSustAquaculDevelopdraftconsult100615.pdf, last accessed on $10 / 07 / 2016$.

Department for Environment, Food \& Rural Affairs (DEFRA, 2015b) Mackerel agreement and support for fisheries affected by Russian ban. At https://www.gov.uk/government/news/mackerelagreement-and-support-for-fisheries-affected-by-russian-ban, last accessed on 08/07/2016.

\section{Council. At}

Economic Development Unit Shetland (EDUS, 2011) Shetland in Statistics. Shetland Islands http://www.shetland.gov.uk/economic development/documents/29523statisticpages 001.pdf, last accessed on 07/07/2016.

European Food Safety Authority (EFSA, 2012) Scientific Opinion on infectious salmon anaemia (ISA). EFSA Journal, 10(11):2971.

European Commission (2010) Environmental, Economic, Social and Governance impacts of the STATUS QUO scenario of the 2012 CFP revision Specific results for 4 case studies Brittany, Galicia, Scotland and Sicily. At

http://ec.europa.eu/fisheries/documentation/studies/4 case studies status quo en.pdf, Accessed on $10 / 12 / 2015$.

European Commission (2013) Strategic Guidelines for the sustainable development of EU aquaculture. COM (2013) 229.

European Commission (2016) Taxation and Customs Union - TARIC Database. At $\underline{\text { http://ec.europa.eu/taxation_customs/dds2/taric/measures.jsp?Lang=en\&SimDate }=20160720 \& \text { Area }=}$ NO\&Taric $=0302 \&$ LangDescr $=e n$, last accessed on 20/07/2016. 
European Market Observatory for Fisheries and Aquaculture Products (EMOFA, 2015) The EU Fish Market. The European Commission, Brussels.

Fisheries and aquaculture software (FishStatJ, 2014) FishStat Plus - Universal software for fishery statistical time series. Updated 28 November 2013. At http://www.fao.org/fishery/, last accessed on 01/07/2016.

Fish Update (2016) Marine Harvest cuts 100 jobs in Scotland. At http://www.fishupdate.com/marine-harvest-cuts-100-jobs-in-scotland/, last accessed on 11/07/2016.

Fish Update (2016b) Jobs go at Shetland Salmon Firm. At http://www.fishupdate.com/jobsgo-at-shetland-salmon-firm/, last accessed on 11/07/2016.

Fisheries Research and Development Corporation (FRDC, 2015) Success through innovation: the National Fishing and Aquaculture RD\&E Strategy 2015. FRDC, Deakin West (ACT), Australia.

Fox, C. J. (2014) Issues around fisheries for small pelagic fish. SAMS Internal Reports 284. Scottish Association for Marine Science, Oban, Scotland: 260 pp. doi: 10.13140/2.1.2396.1600.

Garrett, A. (2010) 2010 survey of the UK seafood processing industry. Summary report. SEAFISH. At

http://www.seafish.org/media/publications/2012_Survey_of_the_UK_Seafood_Processing_Industry.p df, last accessed on 10/07/2016.

Globefish (2013) Fishmeal Fish Oil Commodity Update. Food and Agriculture Organisation of the United, Nations, Rome, Italy.

Globefish (2014) Salmon market report November 2014. At http://www.globefish.org/salmon-october-2014.html, last accessed on 04/12/2015.

Globefish (2015) Salmon market report March 2015. At http://www.globefish.org/salmonmarch-2015.html, last accessed on 12/02/2016.

Globefish (2016) Highlights - A quarterly update on world seafood markets. Food and Agriculture Organisation of the United Nations Rome, Italy.

Good Agricultural Practice (GAP). (2016) Certification for Producers. At http://www.globalgap.org/uk_en/for-producers/, last accessed on 23/02/2016.

Gordon, R. (2011) Terrorism financing indicators for financial institutions in the United States. Case Western Reserve Journal of International Law, 44: 765-803.

Graziano, M., Billing, S-L., Kenter, J., Greenhill, L. (2016) A transformational paradigm for marine renewable energy development. Energy Research and Social Sciences, 23: 126-147.

Hannesson, R. (2014) Do threat of mutually assured destruction produce quasi-cooperation in the mackerel fishery? Marine Policy, 44: 342-350.

Hastings, T., Olivier, G., Cusack, R., Bricknell, I., Nylund, A., Binde, M., Munroe, P., et al. (1999) Infectious Salmon Anaemia. Bulletin of the European Association of Fish Pathologists, 19(6): 286-288.

Havice, E., Campling, L. (2017) Where chain and environmental governance meet: Control relations and conditions of production in the canned tuna global value chain. Economic Geography, 93(3): 292-313.

Henschke, N., Maher, C.G., Ostelo R.W.J.G., de Vet, H.C.W., Macaskill, P., Irwig, L. (2013) Red flags to screen for malignancy in patients with low-back pain. Cochrane Database of Systematic Reviews, Issue 2. Art. No.: CD008686. DOI: 10.1002/14651858.CD008686.pub2. 
Holland, J. (2015) Norway's seafood exports unscathed by Russia's trade ban. At http://www.seafoodsource.com/all-commentary/27645-norway-s-seafood-exports-unscathed-byrussia-s-trade-ban, last accessed on 11/07/2016.

Holling, C. S. (1973) Resilience and stability of ecological systems. Annual Review of Ecology and Systematics, 4:1-23.

Holling, C. S. (1996) Engineering resilience versus ecological resilience. Pages 31-44 in P. C. Schulze, editor. Engineering within ecological constraints. National Academy Press, Washington, D.C., USA

Holter, M. (2014) Norway Unveils Steps to Protect Fish Farmers From Russia Ban. At http://www.bloomberg.com/news/2014-08-22/norway-salmon-farms-can-delay-slaughter-afterrussian-sanctions.html, accessed on 10/07/2016.

Hospes, O., Kentin, A. (2014). In Padt, F., Opdam, P., Polman, N., and Termeer, C. (eds.). Scale-Sensitive governance of the environment $-1^{\text {st }}$ edition. Hoboken (NJ), USA: John Wiley \& Sons.

Huemer, L. (2012). Organizational identities in the networks: Sense-giving and sense-taking in the salmon farming industry. The IMP Journal, 6(3): 240-253.

Hughes, K. M., Dransfeld, L., Johnson, M. P. (2015) Climate and stock influences on the spread and locations of catches in the northeast Atlantic mackerel fishery. Fisheries Oceanography, 24: 540-552.

IceFishNews (2015) Vanishing Atlantic mackerel price premium in Russia. At http://icefishnews.com/vanishing-atlantic-mackerel-price-premium-in-russia/, last accessed on $11 / 07 / 2016$

ICES (2014) Widely distributed and migratory stocks - Mackerel in the Northeast Atlantic (combined Southern, Western, and North Sea spawning components). ICES, Copenhagen, Denmark.

ICES (2014b) Report of the Report of the Working Group on Widely Distributed Stocks (WGWIDE). ICES CM 2014/ACOM: 15. ICES, Copenhagen, Denmark.

ICES (2017) Advice on fishing opportunities, catch, and effort Ecoregions in the Northeast Atlantic and Arctic Ocean Published 29 September 2017, ICES Advice 2017 Mackerel (Scomber scombrus) in subareas 1-8 and 14, and in Division 9.a (the Northeast Atlantic and adjacent waters). DOI: 10.17895/ices.pub.3023, last accessed 06/10/2017.

Jansen, T., Burns, F. (2015) Density dependent growth changes through juvenile and early adult life of North East Atlantic Mackerel (Scomber scombrus). Fisheries Research, 169: 37-44.

Jennings, S., Stentiford, G. D., Leocadio, A. M., Jeffrey, K. R., Metcalfe, J., Katsiadaki, J., Aucheterlonie, N. A., et al. (2016) Aquatic food security: insights into challenges and solutions from an analysis of intercations between fisheries, aquaculture, food safety, human health, fish and human welfare, economy and environment. Fish and Fisheries, in press. DOI: 10.1111/faf.12152.

Jensen, F., Frost, H., Thøgersen, T., Andersen, P., Andersen, J. L. (2015) Game theory and fish wars: The case of the Northeast Atlantic mackerel fishery. Fisheries Research, 172: 7-16.

Johnson, K., Kerr, S., Side, J. (2012). Accomodating wave and tidal energy - Control and decision in Scotland. Ocean \& Coastal Management, 65: 26-33.

Jones, E.V., Caveen, A.J., Gray, T.S. (2014) Are fisheries-dependent communities in Scotland really maritime-dependent communities? Ocean \& Coastal Management, 95: 254-263. 
Jordan, G., Halpin, D. (2006) The Political Coherence: Constructing a Rural Policy for Scotland. Journal of Public Policy, 26(1): 21-41.

Levy, L. B, (2013) Dietary strategies, policy and cardiovascular disease risk reduction in England. Proceedings of the Nutrition Society, 72, 386-389.

Longhurst, A. (2010) Mismanagement of marine fisheries.

Marine Harvest (2008) The Impact of the ISA Virus in Chile. At http://www.thefishsite.com/articles/763/the-impact-of-the-isa-virus-in-chile/, last accessed on $09 / 02 / 2016$.

Marine Harvest (2015) Salmon Farming Industry Handbook 2015. At http://www.marineharvest.com/globalassets/investors/handbook/2015-salmon-industry-handbook.pdf, last accessed on 28/09/2015.

Marine Management Organization (MMO, 2015) UK Sea Fisheries Statistics 2014. At https://www.gov.uk/government/uploads/system/uploads/attachment_data/file/462753/UK_S ea_Fisheries_Statistics_2014___online_version.pdf, last accessed on 11/07/2016.

Marine Scotland Science (2013) Scottish Sea Fisheries Employment 2013. The Scottish Government, Edinburgh, UK.

Martino, D., Stamelou, M., Bhatia, K. P., (2013) The differential diagnosis of Huntington's disease-like syndromes: 'red flags' for the clinician. Journal of Neurology, Neurosurgery \& Psychiatry, 84: 650-656.

Ministerial Group for Sustainable Aquaculture (MGSA, 2014) Aquaculture Science \& Research Strategy. Marine Scotland. At http://www.gov.scot/Resource/0045/00456584.pdf, last accessed on 11/07/2016.

Montero-Serra, I., Edwards, M., Genner, M. J. (2014) Warming shelf seas drive the subtropicalization of European pelagic fish communities. Global Change Biology 21(1): 144-153.

McCall Howard, P. (2012) Sharing or Appropriation? Share Systems, Class and Commodity Relations in Scottish Fisheries. Journal of Agrarian Change, 12(2-3): 316-343.

Motova, A., Natale, F. (2015) Impacts of the 2014 Russian trade ban on seafood. JRC Science and Technology Report EUR 27113. At http://publications.jrc.ec.europa.eu/repository/handle/JRC94726, last accessed on 09/07/2016.

Österblom, H., Jouffray, J-B., Folke, C., Krona, B., Troell, M., Merrie, A., Rockström J. (2015) Transnational corporations as 'Keystone' actors in marine ecosystems. PLoS ONE, 10(5): doi:10.1371/journal.pone.0127533.

Perrings, C. (2006). Resilience and sustainable development. Environment and Development Economics, 11:417-427.

Pita, C. (2010) The human dimensions of marine protected areas: The Scottish fishing industry. PhD thesis, University of Aberdeen, U.K. 255 pp.

Pita, C., Dickey, H., Pierce, G.J., Mente, E., Theodossiou, I. (2010) Willingness for mobility amongst European fishermen. Journal of Rural Studies, 26: 308-319. 
Poppy, G.M., Chiotha, S., Eigenbrod, F., Harvey, C.A., Honzák, Hudson, M.D., Jarvis, A., et al. (2014). Food security in a perfect storm: using the ecosystem services framework to increase understanding. Philosophical Transitions of the Royal Society B, 369.

Rainbird, H. Ramirez, P. (2012). Bringing social institutions into global value chain analysis: the case of salmon farming in Chile. Work, employment and society, 26(5): 789-805. industry. At

Research Council of Norway (2015) New aquaculture programme with a stronger focus on http://www.forskningsradet.no/en/Newsarticle/New aquaculture programme with a stronger focus _on_industry/1254011969069/p1177315753918?WT.ac=forside_nyhet, last accessed on 09/07/2016.

Royal Society for the Prevention of Cruelty to Animals (RSPCA). (2016) Welfare standards for farmed Atlantic salmon. At

\section{http://science.rspca.org.uk/sciencegroup/farmanimals/standards/salmon, last accessed on} $11 / 07 / 2016$.

Rutterford, L. A., Simpson, S. D., Jennings, S., Johnson, M. P., Blanchard, J. L., Schön, P-J., Sims, D. W., et al. (2015) Future fish distributions constrained by depth in warming seas. Nature Climate Change, 5(6): 569-573.

Salz, P., MacFayden, G. (2007) Regional Dependency on Fisheries. European Parliament, Brussels, Belgium. At

http://ec.europa.eu/fisheries/documentation/studies/4_case_studies_status_quo_en.pdf, last accessed on $11 / 07 / 2016$.

\section{Exports. At}

Scottish Salmon Producer's Organization (SSPO, 2014) Draft budget 2015-2016: Increasing

http://www.scottish.parliament.uk/S4_EconomyEnergyandTourismCommittee/Inquiries/Scottish_Sal mon Producers Organisation.pdf, last accessed on 11/07/2016.

Scottish Salmon Producer's Organization (SSPO, 2014b) Sustainable Scottish SalmonScottish Salmon Farming Annual Report 2013. At http://scottishsalmon.co.uk/wpcontent/uploads/2014/04/FINAL-Annual-Report-aug-14.pdf, last accessed on 11/07/2016.

Scottish Government (2015) Scotland's National Marine Plan. At http://www.gov.scot/Resource/0047/00475466.pdf, last accessed on 11/07/2016.

Scottish Government (2015b) Aquaculture Strategy. At http://www.gov.scot/Topics/marine/Fish-Shellfish, last accessed on 10/07/2016.

Seafish (2006) The economic impacts of the UK sea fishing and fish processing sectors: An input-output analysis. At http://www.seafish.org/media/publications/2006_io_key_features_final_090108.pdf, last accessed on 11/07/2016.

Seafish (2013). Industry Brief Note - January 2013. At http://www.seafish.org/media/750990/seafishguidancenote mackerel 201301.pdf, last accessed on $11 / 07 / 2016$.

Seafish (2015) Seafood Industry Factsheet - February 2015. At http://www.seafish.org/media/publications/Seafood_Industry_Factsheet_2015.pdf, last accessed on 10/07/2016. (STV News, 2012 and the Shetland times, 2012

Seafish (2015b) Seafood Industry Overview - Market Summary. At http://www.seafish.org/research-economics/market-insight/market-summary\#consumption, last accesed on 20/07/2016 

http://www.seafish.org/media/Publications/Seafood Consumption Fact Sheet Final.pdf, last accessed on 20/07/2016. bust-eu-quotas-by-85m/ last accessed on 18/07/2016.

Sumaila, U.R., Bellmann, C., Tipping A. (2016) Fishing for the future: An overview of challenges and opportunities. Marine Policy, 69: 173-180.

Sverdrup-Thygeson, B. (2015) The Flexible Cost of Insulting China: Trade Politics and the

Tacon, A.G.J., Hasan, M.R., Metian, M. (2011) Demand and supply of feed ingredients for farmed fish and crustaceans, Food and Agriculture Organisation of the United Nations No. 564. Rome, Italy.

The Shetland Times (2012) Thirteen Shetland fishermen fined $£ 470,000$ for 'cynical and sophisticated' black fish scheme. At http://www.shetlandtimes.co.uk/2012/02/24/thirteen-shetlandfishermen-fined-470000-for-cynical-and-sophisticated-black-fish-scheme last accessed on 18/07/2016.

Thurstan, R.H., Roberts, C.M. (2012) The past and future of fish consumption: Can supplies meet healthy eating recommendations? Marine Pollution Bulletin, 89: 5-11.

Tocher, D. R. (2015) Omega-3 long-chain polyunsaturated fatty acids and aquaculture in perspective. Aquaculture, 449: 94-107.

van der Kooij, J., Fässler, S. M. M., Stephens, D., Readdy, L., Scott, D. E., Roel, B. A. (2015) Opportunistically recorded acoustic data support Northeast Atlantic mackerel expansion theory. ICES Journal of Marine Science, in press. doi: 10.1093/icesjms/fsv243.

Ytrestøyl, T., Aas, T.S, Åsgård, T. (2015) Utilisation of feed resources in production of Atlantic salmon (Salmo salar) in Norway, Aquaculture, 448:365-374.

Yucel, E. (2013) Effectiveness of Red Flags in Detecting Fraudulent Financial Reporting: An Application in Turkey, Journal of Accounting and Finance 60: 139-158.

Voss R., Hoffmann, J., Llope, M., Schmidt J.O, Möllmann, C., Quaas M.F. Political overfishing: Social-economic drivers in TAC setting decisions. University of Kiel Working Papers. At http://www.eree.uni-kiel.de/de/mitarbeiterinnenmitarbeiter/Political\%20overfishing\%2011\%20Sep_Julia.pdf, last accessed on 11/07/2016 